\title{
TRANSPARANSI PENGELOLAAN KEUANGAN DAERAH DI DINAS KESEHATAN KOTA MAKASSAR
}

\author{
Fahril ${ }^{1,}$ Mappamiring 2 , Rudi Hardi ${ }^{1}$ \\ ${ }_{1}^{1}$ Program Studi Ilmu Pemerintahan Fakultas Ilmu Sosial dan Ilmu Politik \\ Universitas Muhammadiyah Makassar \\ Jl Sultan Alauddin No 259 Makassar 90221 \\ Telp. 0411-866972 ext. 107. Fax. 0411-8655888 \\ fahrilumm@yahoo.co.id \& rudi_hardi@gmail.com \\ 2 Program Studi Ilmu Adminitrasi Negara Fakultas Ilmu Sosial dan Ilmu Politik \\ Universitas Muhammadiyah Makassar \\ Jl Sultan Alauddin No 259 Makassar 90221 \\ Telp. 0411-866972 ext. 107. Fax. 0411-8655888 \\ mappamiring@yahoo.com
}

\begin{abstract}
The purpose of this study to determine the transparency of financial management at the Health Agency of Makassar. This type of research is descriptive qualitative approach and the type used is phenomenological. The results showed that there is a supply of information with clarity indicator procedures, clarity of costs are not transparent. There is easy access to information with indicators of the ease of getting information directly or indirectly. There are complaints mechanism for complaints to the service users. publication activities on mass media activity has been carried out but not optimal in non-governmental institutions. Efforts made in the Makassar Health Agency financial liability in accordance with applicable regulations. To ensure internal and external transparency Makassar Health Agency has been building websites as a medium of socialization and dissemination of financial accountability.
\end{abstract}

keywords: transparency, financial management, health

\section{ABSTRAK}

Tujuan penelitian ini untuk mengetahui transparansi pengelolaan keuangan pada Dinas Kesehatan Kota Makassar. Jenis penelitian yang digunakan adalah pendekatan deskriptif kualitatif dan tipe yang digunakan yaitu fenomenologi. Hasil penelitian menunjukkan bahwa terdapat penyediaan informasi dengan indikator kejelasan prosedur-prosedur, kejelasan biayabiaya belum transparan. Ada kemudahan akses informasi dengan indikator kemudahan mendapatkan informasi langsung maupun tidak langsung. Tersedia mekanisme pengaduan untuk komplain kepada pengguna layanan . kegiatan publikasi kegiatan pada media massa telah dilakukan namun belum optimal pada lembaga non pemerintah. Upaya yang dilakukan Dinas Kesehatan dalam pertanggungjawaban keuangan telah sesuai dengan regulasi yang berlaku. Untuk menjamin trasparansi internal dan eksternal Dinas Kesehatan Makassar telah membangun website sebagai media sosialisasi dan diseminasi pertanggungjawaban keuangan.

kata kunci: transparansi, pengelolaan keuangan, kesehatan 


\section{A. PENDAHULUAN}

Pelaksanaan perundangundangan bidang keuangan negara telah dikeluarkan berbagai aturan pelaksanaan dalam bentuk Peraturan Pemerintah antara lain: Peraturan Pemerintah Nomor 20 Tahun 2004 tentang Rencana Kerja Pemerintah dan Peraturan Pemerintah Nomor 21 Tahun 2004 tentang Rencana Kerja dan Anggaran Kementerian Negara/Lembaga, Peraturan Pemerintah Nomor 24 Tahun 2004 tentang Standar Akuntansi Pemerintahan, dan lain-lain. Berkenaan dengan pengelolaan Keuangan Daerah dikeluarkan Peraturan Pemerintah Nomor 58 Tahun 2005 tentang Pengelolaan Keuangan Daerah. Sebagai tindak lanjut Peraturan Pemerintah Nomor 58 Tahun 2005, Menteri Dalam Negeri telah mengeluarkan Peraturan Menteri Dalam Negeri Nomor 13 Tahun 2006 tentang Pedoman Pengelolaan Keuangan Daerah, dan terakhir telah direvisi dengan Peraturan Menteri Dalam Negeri Nomor 59 Tahun 2007 tentang Perubahan Atas Peraturan Menteri Dalam Negeri Nomor 13 Tahun 2006 tentang Pedoman Pengelolaan Keuangan Daerah.

Pengelolaan keuangan daerah merupakan salah satu bagian yang mengalami perubahan mendasar dengan ditetapkannya UU No.32 tahun 2004 tentang Pemerintah Daerah dan UU No.33 tahun 2004 tentang Perimbangan Keuangan antara Pemerintah Pusat dan Pemerintah Daerah. Kedua Undangundang tersebut telah memberikan kewenangan lebih luas kepada pemerintah daerah. Kewenangan dimaksud diantaranya adalah keleluasaan dalam mobilisasi sumber dana, menentukan arah, tujuan dan target penggunaan anggaran, demikian pula dengan otoritas Dinas Kesehatan Kota Makassar untuk mengelola sumber-sumber pendapatan baik dari pendapatan APBN maupun dari APBD.

Tuntutan transparansi dalam system SKPD semakin meningkat pada era reformasi saat ini, tidak terkecuali transparansi dalam pengelolaan keuangan daerah di Dinas Kesehatan Kota Makassar. Pejabat yang berwenang pada bidang keuangan kantor pada biro keuangan diwajibkan menyusun laporan pertanggungjawaban yang menggunakan sistem akuntansi yang diatur oleh pemerintah pusat dalam bentuk Undang-undang dan Peraturan Pemerintah yang bersifat mengikat seluruh elemen pejabat pelaksana keuangan daerah. Dimana pengawasan pengelolaan anggaran tiap tahun dilakukan dengan menggunakan sistem pelaporan dengan pencatatan yang disertai bukti-bukti pengeluaran.

Pemaparan peraturan pemerintah terkait pengelolaan anggaran menajadi alasan bagi penulis dalam mengkaji implementasi peraturan tersebut pada Dinas Kesehatan Kota Makassar. Untuk itu penelitian ini berkaitan pengelolaan keuangan daerah yang transparansi di dinas kesehatan kota Makassar dan mengetahui sejauh mana usaha yang dilakukan oleh dinas kesehatan dalam konsep transparansi pengelolaan keuangan daerah.

\section{B. TINJAUAN PUSTAKA}

Transparansi adalah memberikan informasi keuangan yang terbuka dan jujur kepada masyarakat berdasarkan pertimbangan bahwa masyarakat memiliki hak untuk mengetahui 
secara terbuka dan menyeluruh atas pertanggungjawaban pemerintah dalam pengelolaan sumber daya yang dipercayakan kepadanya dan ketaatannya pada peraturan perundang-undangan. Transparansi dan akuntabilitas pengelolaan keuangan daerah merupakan salah satu bentuk efektivitas dan efisiensi penyelenggaraan tata kelola pemerintahan yang baik (good governance government).

Menurut Andrianto, (2007: 35) transparansi adalah keterbukaan dan kejujuran kepada masyarakat berdasarkan pertimbangan bahwa masyarakat memiliki hak mengetahui secara terbuka dan menyeluruh atas pertanggung jawaban pemerintahan dalam sumber daya yang di percayakan kepadanya dan ketaatannya pada peraturan perundang-undangan. Transparansi adalah keterbukaan atas semua tindakan dan kebijakan yang diambil oleh pemerintah (Hamid Muhammad 2007: 31). Transparansi merupakan keterbukaan pemerintah kepada masyarakat untuk mengakses informasi berdasarkan pertimbangan bahwa masyarakat memiliki hak untuk mengetahui secara terbuka dan menyeluruh atas pertanggung jawaban pemerintah tersebut.

Transparansi dibangun atas dasar kebebasan memperoleh informasi yang dibutuhkan oleh masyarakat. Artinya, informasi yang berkaitan dengan kepentingan publik secara langsung dapat diperoleh oleh mereka yang membutuhkan (Mardiasmo, 2009: 34). Transparansi mengisyaratkan bahwa laporan tahunan tidak hanya dibuat tetapi juga terbuka dan dapat diakses oleh masyarakat, karena aktivitas pemerintah adalah dalam rangka menjalankan amanat rakyat. Sekarang ini, banyak negara mengklasifikasikan catatan atau laporan sebagai top secret, secret, confidential dan restricted, dan official secrets acts membuat unauthorized disclosure terhadap suatu criminal offence. Kultur secara umum di banyak negara, baik negara maju maupun negara berkembang, adalah kerahasian (Shende dan Bennet, 2004 :80).

Adapun Indikator transparansi yaitu prinsip yang menjamin akses atau kebebasan bagi setiap orang untuk memperoleh informasi tentang penyelenggaraan pemerintahan, yakni informasi mengenai kebijakan, proses pembuatan, pelaksanaan, dan hasil yang dicapai.

Tujuan transparansi adalah menyediakan informasi keuangan terbuka bagi masyarakat dalam rangka mewujudkan pemerintahan yang baik (Good Governance) dan untuk menciptakan timbal balik antara Dinas Kesehatan dengan publik. Penerapan trasparansi ditujukan untuk membangun kepercayaan dan keyakinan publik kepada Dinas Kesehatan Kota Makassar adalah satuan kerja perangkat daerah yang bersih dalam arti tidak korupsi dan berwibawa dalam arti professional dalam melaksanakan tugasnya.

Instrumen utama dari akuntabilitas keuangan adalah anggaran pemerintah, data yang secara periodik dipublikasikan, laporan tahunan dan hasil investigasi dan laporan umum lainnya yang disiapkan oleh agen yang independen. Anggaran tahunan secara khusus mempunyai otoritas legal untuk pengeluaran dana publik, sehingga proses penganggaran secara keseluruhan menjadi relevan untuk manajemen fiskal dan untuk 
melaksanakan akuntabilitas keuangan dan pengendalian pada berbagai tingkat operasi (Shende dan Bennet, 2004 ;87).

Dalam Peraturan Pemerintah 58 Tahun 2005 (Pasal 1), keuangan daerah adalah semua hak dan kewajiban daerah dalam rangka penyelenggaraan pemerintah daerah yang dapat dinilai dengan uang, termasuk di dalamnya segala bentuk kekayaan yang berhubungan dengan hak dan kewajiban daerah terebut. Bila dilihat dari ruang lingkupnya, keuangan daerah meliputi kekayaan daerah yang dikelola langsung oleh pemerintah daerah dan kekayaan daerah yang dipisahkan pengurusannya. Kekayaan daerah yang dikelola langsung oleh pemerintah daerah meliputi APBD dan barang-barang inventaris milik daerah. Sedangkan kekayaan daerah yang dipisahkan pengurusannya meliputi badan-badan usaha milik daerah (Halim, 2002:34).

Uraian di atas dapat disimpulkan bahwa transparansi keuangan daerah adalah pertanggungjawaban pemerintah daerah berkenaan dengan pengelolaan keuangan daerah kepada publik secara terbuka dan jujur melalui media berupa penyajian laporan keuangan yang dapat diakses oleh berbagai pihak yang berkepentingan dengan anggapan bahwa publik berhak mengetahui informasi tersebut. Keuangan daerah adalah semua hak dan kewajiban daerah dalam rangka penyelenggaraan pemerintahan daerah yang dapat dinilai dengan uang termasuk didalamya segala bentuk kekayaan yang berhubungan dengan hak dan kewajiban daerah tersebut.
Menurut Tjahjanulin (2002 : 52) pengelolaan keuagan adalah proses pengurusan, penyelengaraan, penyediaan, dan penggunaan uang dalam setiap usaha kerjasama sekelompok orang untuk tercapai suatu tujuan. Proses ini tersusun dari pelaksanaan fungsi-fungsi penganggaran pembukuan dan pemeriksaan atau secara operasioal apabila dirangkaikan dengan daerah maka pengelolaan keuangan daerah adalah pelaksanaan meliputi penyusunan, penetapan, pelaksanaan pengawasan dan perhitungan anggaran pendapan dan belanja daerah (APBD).

Pengelolaan keuangan daerah adalah keseluruhan kegiatan yang meliputi perencanaan, pelaksanaan, penatausahaan, pelaporan, pertanggungjawaban, dan pengawasan keuangan daerah.

Menurut Chabib Soleh dan Rohcmansjah Heru (2010:10), prinsip-prinsip pengelolaan keuangan yang diperlukan untuk mengontrol kebijakan keuangan daerah meliputi: (1) Akuntabilitas; (2) Value for Money; (3) Kejujuran dalam mengelola keuangan publik (Probity); Transparansi; (5) Pengendalian.

Paradigma baru pengelolaan keuangan daerah (APBD) didorong oleh hal-hal yaitu: Meningkatnya tuntutan masyarakat daerah terhadap pengelolaan APBD secara transparan dan akuntabel, Pemberlakuan Undang-undang Pemerintah Daerah dan Undang-undang tentang Perimbangan Keuangan Daerah yang baru serta peraturan pelaksanaanya dan sistem, prosedur dan format struktur APBD yang berlaku selama ini dinilai kurang mampu mendukung tuntutan perubahan sehingga perlu perencanaan APBD yang sistematis, terstruktur dan komprehensif. 
Azas umum pengelolaan keuangan daerah terdapat dalam Permendagri No.13 Tahun 2006 tentang Pedoman Pengelolaan Keuangan Daerah, yang tertuang didalam Bab I pasal 4 yang berbunyi bahwa keuangan daerah perlu dikelola dengan menggunakan azas sebagai berikut: Secara tertib, Taat pada peraturan perundang-undangan, efektif, efisien, ekonomis, transparan, bertanggung jawab, keadilan, keseimbangan distribusi kewenangan dan pendanaannya atau keseimbangan distribusi hak dan kewajiban berdasarkan pertimbangan yang objektif, kepatuhan dan manfaat untuk masyarakat azas umum pengelolaan keuangan daerah harus diimplementasikan dalam prakteknya mengelola keuangan daerah, agar laporan keuangan pemerintah yang disajikan dapat mencerminkan kinerja keuangan pemerintah selama periode tersebut.

Dalam rangka pertanggung jawaban publik, pemerintah daerah seharusnya melakukan optimalisasi anggaran yang dilakukan secara efisien dan efektif untuk meningkatkatkan kesejahteraan masyarakat. Pengalaman yang terjadi selama ini menunjukkan bahwa manajemen keuangan daerah masih memperhatinkan. Anggaran daerah, khusunya pengeluaran daerah belum mampu berperan sebagai insentif dalam mendorong laju pembangunan daerah. Disamping itu, banyak ditemukan keluhan masyarakat yang berkaitan dengan pengalokasian anggaran yang tidak sesuai dengan kebutuhan dan skala prioritas, serta kurang mencerminkan aspek ekonomi, efisiensi dan efektivitas, keadilan dan pemerataan. Pengelolaan keuangan daerah, khususnya pengelolaan anggran daerah, dalam konteks otonomi dan desentralisasi menduduki posisi yang sangat penting. Namun hingga saat ini, kualitas perencanaan anggaran daerah yang digunakan masih relative rendah. Hal ini dapat dimengerti oleh karena masih banyak aparatur daerah maupun aparatur pemerintah pusat yang belum sepenuhnya bisa meninggalkan cara berfikir lama.

Gejala ini nampak dari ketidakberanian aparatur daerah untuk mengambil keputusan, sekalipun hal itu berada dalam ranah kekuasaannya. Kebiasaan mohon petunjuk pelaksanaan adalah sesuatu yang sangat lumrah yang menjadi pemandangan keseharian. Akibatnya, proses anggaran daerah dengan paradigma lama cenderung lebih sentralisasi. Perencanaan anggaran didominasi dan diintervensi oleh pemerintah pusat dalam rangka mengakomodasikan kepentingan pusat di daerah.

Kebijakan yang diambil oleh pemerintah daerah hanya mengikuti petunjuk dari pemerintah pusat dan atau pemerintah atasan. Lemahnya perencanaan anggaran juga diikuti dengan ketidakmampuan pemerintah daerah dalam meningkatkan penerimaan daerah secara berkesinambungan. Sementara itu, pengeluaran daerah terus meningkat secara dinamis, sehingga hal tersebut meningkatkan fiscal gap. Keadaan tersebut pada akhirnya memunculkan kemungkinan underfinancing atau overfinancing yang dapat mempengaruhi tingkat efisiensi dan efektivitas unit-unit kerja pemerintah daerah harus disusunberdasarkan pendekatan kinerja. Untuk menyusun anggarandaerah dengan pendekatan kinerja tersebut dapat digunakan model analisis standar belanja (ASB). Heru, (2010 :34). 
Menurut Tjahjanulin (2002: 53) tujuan pengelolaan keuangan daerah adalah Memanfaatkan semaksimal mungkin sumber suatu pendapaatan daerah, Setiap anggaran daerah yang disusun diusahakan perbaikan dari anggaran sebelumnya, Sebagai landasan formal dari suatu kegiatan yang lebih teralah dan teratur dan memudahkan melakukan pengawasan, Memudahkan koordinasi masing-masing institusi dan dapat diarahkan sesuai dengan apa yang diprioritaskan dan ditujuh oleh pemerintah daerah dan Untuk menampung dan menganalisa serta memudahakan dalam pengambilan keputusan tentang alokasi pembiayaan proyek-proyek atau kebutuhan lain yang diajukan oleh masing-masing institusi.

\section{METODE PENELITIAN}

Penelitian ini menggunakan penelitian kualitatif dan penelitian kuantitatif. Pendekatan penelitian kualitatif merupakan pendekatan yang memerlukan pemahaman yang mendalam dan menyeluruh berhubungan dengan objek yang diteliti untuk menjawab permasalahan untuk mendapatkan data-data kemudian dianalisis dan mendapatkan kesimpulan penelitian dalam situasi dan kondisi tertentu. Sedangkan penelitian Kuantitatif adalah pendekatan yang mementingkan adanya variablevariabel sebagai obyek penelitian dan variable tersebut didefenisikan dalam bentuk operasionalisasi variable masing-masing seperti disajikan dalam bentuk table frekuensi dan distribusi.

Jenis data yang digunakan dalam penelitian ini adalah data Kualitatif yaitu data yang berbentuk kata, kalimat, skema dan gambar yang dijadikan dasar dalam memecahkan permasalahan yang ada dan data Kuantitatif adalah data yang berbentuk angka yang kemudian diolah dan dibuatkan suatu interprestasi dalam upaya menjawab permasalahan yang ada. Sumber data yaitu data primer dan sekunder. Teknik pengumpulan data dalam penelitian ini yaitu observasi, wawancara, kuesioner dan dokumentasi.

\section{HASIL DAN PEMBAHASAN}

\section{Transparansi Pengelolaan Keuangan Daerah Di Dinas Kesehatan Kota Makassar.}

Transparansi adalah prinsip yang menjamin akses atau kebebasan bagi setiap orang untuk memperoleh informasi tentang penyelenggaraan pemerintah, yakni informasi tentang kebijakan, proses pembuatan dan pelaksanaannya, serta hasil-hasil yang dicapai. Indikator-indikator transparansi adalah sebagai berikut: (1) Penyediaan informasi yang jelas tentang prosedur-prosedur, biayabiaya dan tanggung jawab, (2) Kemudahan akses informasi, (3) Menyusun suatu mekanisme pengaduan jika ada peraturan yang dilanggar atau permintaan untuk membayar uang suap, (4) Meningkatkan arus informasi melalui kerjasama dengan media massa dan lembaga non pemerintah.

\section{a. Penyediaan Informasi}

Penyediaan informasi adalah sebuah wujud layanan dari salah satu bentuk transparansi dengan indikator; informasi prosedurprosedur yang jelas dan biaya-biaya. Data yang dihimpun dari responden untuk variable penyediaan informasidengan indikator penyediaan informasi prosedur- 


\section{otoritas}

prosedur yang jelas tampak pada tabel berikut:

\section{Tabel 1}

\section{DistribusiTanggapan Responden tentang Penyediaan Informasi Prosedur-Prosedur yang jelas}

\begin{tabular}{|c|c|}
\hline $\begin{array}{c}\text { Kategori } \\
\text { Jawaban }\end{array}$ & $\begin{array}{c}\text { Frekuensi } \\
\text { (Orang) }\end{array}$ \\
\hline Sangat Transparan & - \\
\hline Transparan & - \\
\hline Cukup Transparan & 8 \\
\hline Tidak Transparan & 12 \\
\hline Jumlah & $\mathbf{2 0}$ \\
\hline
\end{tabular}

Sumber data: Hasil Olahan Data Kuesioner, 2014

Pada indikator penyediaan informasi tentang prosedur-prosedur yang jelas, tidak terdapat tanggapan pada kategori sangat transparan, tidak terdapat tanggapan pada kategori transparan, terdapat 7 orang yang memberi tanggapan cukup transparan, terdapat 13 orang yang memberi tanggapan tidak transparan. Kategori terbesar berada pada kategori tidak transparan sebanyak 13 orang.

Selanjutnya data yang dihimpun dari responden untuk variable penyediaan informasi dengan indikator biaya-biaya yang jelas tampak pada tabel berikut:
Tabel 2

DistribusiTanggapan Responden Tentang Biaya-Biaya yang Jelas

\begin{tabular}{|c|c|}
\hline $\begin{array}{c}\text { Kategori } \\
\text { Jawaban }\end{array}$ & $\begin{array}{c}\text { Frekuensi } \\
\text { (Orang) }\end{array}$ \\
\hline Sangat Transparan & - \\
\hline Transparan & - \\
\hline Cukup Transparan & 7 \\
\hline Tidak Transparan & 13 \\
\hline Jumlah & $\mathbf{2 0}$ \\
\hline
\end{tabular}

Sumber data: Hasil Olahan Data Kuesioner, 2014

Pada indikator penyediaan informasi tentang biaya-biaya yang jelas, tidak terdapat tanggapan pada kategori sangat transparan, tidak terdapat tanggapan pada kategori transparan, terdapat 8 orang yang memberi tanggapan cukup transparan, terdapat 12 orang yang memberi tanggapan tidak transparan. Kategori terbesar berada pada kategori tidak transparan sebanyak 12 orang.

Berdasarkan hasil pengamatan penulis bahwa variabel penyediaan informasi dengan indikator penyediaan informasi prosedurprosedur yang jelas yang dilakukan dinas kesehatan kota Makassar belum dilakukan dengan baik sesuai dengan prinsip transparansi. Sebagaimana hasil tanggapan responden dengan ke dua indikator di atas menunjukkan hasil dengan rata-rata berada pada kategori tidak transparan.

\section{b. Kemudahan akses informasi}

Kemudahan akses informasi adalah kemudahan mendapatkan informasi baik secara langsung maupun tidak langsung. Akses informasi secara langsung yaitu informasi yang didapatkan dengan langsung berhadapan dengan pihak terkait mengenai informasi yang 
dibutuhkan. Informasi tidak langsung adalah informasi yang didapatkan melaui media perantara seperti penggunaan IT, pengumaman lewat brosur, pamplet dll. Berikut data yang dihimpun dari responden untuk variabel kemudahan akses informasi dengan indikator akses informasi secara langsung tampak pada tabel berikut:

\section{Tabel 3}

DistribusiTanggapan Responden Tentang Informasi secara langsung

\begin{tabular}{|c|c|}
\hline $\begin{array}{c}\text { Kategori } \\
\text { Jawaban }\end{array}$ & $\begin{array}{c}\text { Frekuensi } \\
\text { (Orang) }\end{array}$ \\
\hline Sangat Mudah & 3 \\
\hline Mudah & 6 \\
\hline Cukup Mudah & 9 \\
\hline Sulit & 2 \\
\hline Jumlah & $\mathbf{2 0}$ \\
\hline
\end{tabular}

Sumber data: Hasil Olahan Data Kuesioner, 2014

Pada indikator akses informasi secara langsung, terdapat 3 orang yang memberi tanggapan sangat mudah, terdapat 6 orang yang memberi tanggapan mudah, terdapat 9 orang yang memberi tanggapan cukup mudah, dan terdapat 2 orang yang memberi tanggapan sulit. Kategori terbesar berada pada kategori cukup mudah sebanyak 9 orang.

Selanjutnya data yang dihimpun kemudahan akses informasi dengan indikator akses informasi tidak langsung tampak pada tabel berikut:
Tabel 4

DistribusiTanggapan Responden

Tentang Akses Informasi Tidak Langsung

\begin{tabular}{|c|c|}
\hline $\begin{array}{c}\text { Kategori } \\
\text { Jawaban }\end{array}$ & $\begin{array}{c}\text { Frekuensi } \\
\text { (Orang) }\end{array}$ \\
\hline Sangat Mudah & - \\
\hline Mudah & 5 \\
\hline Cukup Mudah & 9 \\
\hline Sulit & 6 \\
\hline Jumlah & $\mathbf{2 0}$ \\
\hline
\end{tabular}

Sumber data: Hasil Olahan Data Kuesioner, 2014

Pada indikator akses informasi tidak langsung, tidak terdapat tanggapan pada kategori sangat mudah, terdapat 5 orang yang memberi tanggapan mudah, terdapat 6 orang yang memberi tanggapan cukup mudah, dan terdapat 9 orang atau yang memberi tanggapan sulit. Kategori terbesar berada pada kategori cukup mudah sebanyak 9 orang.

Terkait kemudahan akses informasi baik secara langsung maupun tidak langsung telah dilakukan, namun kedua cara ini memiliki kelebihan dan kelemahan masing-masing. Kelebihan informasi yang dapat di akses secara langsung adalah kejelasan informasi karena mendapatkan penjelasan yang detail sementara kelemahannya adalah keberadaan pimpinan untuk memperoleh informasi yang jarang berada di kantor karena kesibukannya. Kelebihan informasi yang bisa diakses melalui media adalah informasi yang bisa diakses tanpa membutuhkan waktu yang lama. Sementara kelemahannya adalah seringnya penggunaan bahasa yang multi tafsir dan kurang dipahami. 
c. Menyusun suatu mekanisme pengaduan jika ada peraturan yang dilanggar atau permintaan untuk membayar uang suap

Menyusun suatu mekanisme pengaduan jika ada peraturan yang dilanggar atau permintaan untuk membayar uang suap merupakan salah satu prinsip dari transparansi pengeloaan keuangan dengan indikator pelayanan pengaduan. Berikut data yang dihimpun dari responden untuk indikator mengadakan pelayanan pengaduan tampak pada tabel berikut:

\section{Tabel 5}

DistribusiTanggapan Responden

\begin{tabular}{|c|c|}
\hline $\begin{array}{c}\text { Kategori } \\
\text { Jawaban }\end{array}$ & $\begin{array}{c}\text { Frekuensi } \\
\text { (Orang) }\end{array}$ \\
\hline Sangat sering & - \\
\hline Sering & - \\
\hline Cukup sering & 7 \\
\hline Tidak Pernah & 13 \\
\hline Jumlah & $\mathbf{2 0}$ \\
\hline
\end{tabular}

Tentang Pelayananan Pengaduan Sumber data: Hasil Olahan Data Kuesioner, 2014

Pada indikator pelayanan pengaduan, tidak terdapat tanggapan pada kategori sangat sering, tidak terdapat tanggapan pada kategori sering, terdapat 7 orang yang memberi tanggapan cukup sering, dan terdapat 13 orang yang memberi tanggapan tidak pernah. Kategori terbesar berada pada kategori tidak pernah sebanyak 13 orang.

Dari hasil kuesioner dan hasil wawancara dengan beberpa informan terlihat ada perbedaan persepsi tentang layanan pengaduan. Di satu sisi informasi dari responden mengatakan layanan pengaduan cukup sering dilakukan. Sementara di sisi lain dari informasi informan mengatakan layanan pengaduan ini belum maksimal. Dari hasil pengamatan penulis menunjukkan bahwa layanan pengaduan dinas kesehatan kota Makassar dilakukan sesuai dengan aturan yang ada, walau pun hal ini ditandai dengan adanya layanan telepon seluler untuk pengaduan yang langsung terhubung dengan biro terkait dan adanya kotak saran dan kritik yang disediakan. Hanya saja penulis tidak mendapatkan data yang jelas tentang seberapa sering layanan pengaduan itu ditindak lanjuti oleh pihak instansi.

\section{d. Meningkatkan Arus Informasi Melalui Kerjasama dengan Media Massa.}

Meingkatkan arus informasi melalui kerjasama media massa dan lembaga non pemerintah adalah salah satu prinsip transparansi pengelolaan keuangan. Untuk mengukur sejauh mana prinsip transparansi, berikut data yang dihimpun dari responden untuk indikator kerjasama dengan media massa tampak pada tabel berikut:

Tabel 6

DistribusiTanggapan Responden Tentang Kerjasama dengan Media Massa

\begin{tabular}{|c|c|}
\hline $\begin{array}{c}\text { Kategori } \\
\text { Jawaban }\end{array}$ & $\begin{array}{c}\text { Frekuensi } \\
\text { (Orang) }\end{array}$ \\
\hline Sangat Sering & - \\
\hline Sering & - \\
\hline Cukup Sering & 6 \\
\hline Tidak Pernah & 14 \\
\hline Jumlah & $\mathbf{2 0}$ \\
\hline
\end{tabular}

Sumber data: Hasil Olahan Data Kuesioner, 2014

Pada indikator kerjasama dengan media massa, tidak terdapat tanggapan pada kategori sangat sering, tidak terdapat tanggapan pada kategori sering, terdapat 6 orang yang 
memberi tanggapan cukup sering, dan terdapat 14 orang yang memberi tanggapan tidak pernah. Kategori terbesar berada pada kategori tidak pernah sebanyak 14 orang. Hal ini belum jelas terlihat intensitas kerjasama yang dilakukan oleh dinas kesehatan kota makassar dengan media massa. Dari hasil penelusuran penulis ketika berbincang dengan bagian humas, bahwa kerjasama ini biasa dilakukan. Tidak hanya dengan media massa tetapi juga dengan lembaga-lembaga non pemerintah seperti pelibatan LSM dan kerja sama dengan pihak instansi lain. Akan tetapi berita yang diekspos atau dipumblikasikan bukanlah informasi yang mengenai pengelolaan keuangan akan tetapi kegiatan-kegiatan yang dilakukan dinas kesehatan itupun tidak setiap kegiatannya mengundang media untuk meliputnya.

Secara keseluruhan peneliti menyimpulkan bahwa transparansi adalah pemberian informasi dan pengungkapan (disclosure) atas aktivitas dan kinerja finansial kepada pihak-pihak yang berkepentingan. Dinas Kesehatan Kota Makassar, harus dapat menjadi subyek pemberi informasi dalam rangka pemenuhan hak-hak publik yaitu hak untuk tahu, hak untuk diberi informasi, dan hak untuk didengar aspirasinya.

\section{Upaya Yang Dilakukan Dalam Pengelolaan Keuangan Daerah Agar Transparan Di Dinas Kesehatan Kota Makassar.}

a. Konsistensi Laporan

Dengan penyampaian laporan pertangguang jawaban keuangan yang memenuhi prinsip tepat waktu dan dapat diandalkan dan telah disahkan sesuai dengan UU ini adalah upaya yang dilakukan oleh dinas kesehatan kota Makassar agar masyarakat lebih mengetahui sejauh mana pelaporan yang dilakukan oleh dinas kesehatan apakah sesuai dengan UU yang telah di keluarkan oleh pemerintah.

Berikut hasil kutipan wawancara dengan informan terkait dengan upaya yang dilakukan dalam pengelolaan keuangan daerah agar transparansi seperti berikut ini:

"kami sudah melakukan beberapa upaya dalam mewujudkan transparansi, tapi kami juga butuh kerja sama dari semua pihak yang terkait agar kedepannya dapat lebih sempurna lagi dan dapat mewujudkan prinsip-prinsip Good Government dinas kesehatan ini". (wawancara, AJ). Selanjutnya upaya yang dilakukan dalam pengelolaan keuangan daerah agar transparansi informan memaparkan:

"itu memang sudah tugas dari setiap instansi dalam mewujudkan good government memang harus melakukan beberapa trobosan dalam meningkatkan kepercayaan terhadap masyarakat agar masyarakat juga dapat mengetahui apa saj yang dilakukan oleh dinas-dinas atau instansi khususnya di dinas kesehatan kota makassar adalah salah satu instansi yang mendapatkan anggaran yang besar dari APBD". (wawancara, $A B)$.

Alhasil upaya yang dilakukan oleh dinas kesehatan dengan indikator penyampaian laporan pertanggungjawaban keuangan yang memenuhi prinsip tepat waktu dan dapat diandalkan (reliable) dan telah disahkan sesuai dengan UU ini sudah dilakukan sesuai dengan Peraturan 
Pemerintah Nomor 58 Tahun 2005, Menteri Dalam Negeri telah mengeluarkan Peraturan Menteri Dalam Negeri Nomor 13 Tahun 2006 tentang Pedoman Pengelolaan Keuangan Daerah. Ini selaras dengan Menurut Saprianto (2005:15) menyatakan bahwa "melalui transparansi akan memberikan informasi yang terbuka dan jujur kepada masyarakat berdasarkan pertimbangan bahwa masyarakat memiliki hak untuk mengetahui secara terbuka dan menyeluruh atas pertanggung jawaban pemerintah dalam pengelolaan sumber daya yang dipercayakan kepadanya dan ketaatannya pada peraturan perundang-undangan"

b. Pembuatan Website Kantor Dinas Kesehatan Kota Makassar.

Pembuatan website adalah salah satu terobosan baru yang dilakukan oleh dinas kesehatan agar masyarakat dapat mengakses dengan mudah informasi yang dibutuhkan dan masyarakat juga dapat melihat semua agenda atau kegiatan yang dilakukan oleh dinas kesehatan. Berikut hasil kutipan wawancara dengan informan terkait dengan upaya yang dilakukan dalam pengelolaan keuangan daerah agar transparansi seperti berikut ini:

"baguslah kalau dinas kesehatan memiliki upaya seperti itu artinya dinas kesehatan, ini memang mempunyai niat untuk menjadikan instansinya sebagai salah satu instansi pemerintahan yang menerapkan prinsip-prinsip good govermant dan itu pasti masyarakat juga akan mendudukung karena masyarakat akan merasa puas dengan informasi yang dia butuhkan nantinya dan masyarakat juga tau berapa anggaran yang dikelola oleh dinas kesehatan." (wawancara, $A L)$

Upaya yang dilakukan dinas kesehatan kota Makassar dengan indikator pembuatan website dinas kesehatan kota makassar itu semua adalah upaya yang baik yang dilakukan dinas kesehatan dan pasti masyarakat bisa menilai sejauhmana usaha dari dinas kesehatan agar dapat menjadi suatu instansi yang transparan dan dapat dipercaya dan tidak menimbulkan pertanyaan terhadap masyarakat seberapa banyak biaya yang dikelolah oleh dinas kesehatan kota makassar apa lagi dinas kesehatan ini salah satu instansi yang mendapatkan APBD terbanyak di Kota Makassar.

Hal ini selaras dengan teori transparansi yang dipaparkan oleh Krina (2003: 17) yakni bagaimana seharusnya pemerintah daerah memuaskan rasa keingintahuan dari masyarakat tentang jalannya pemerintahan daerah mereka dengan cara mentranparansikan laporanlaporan kegiatan yang telah dilakukan oleh pemerintah daerah dan juga bagaimana pemerintah daerah dapat mengetahui aspirasi masyarakat dengan menyediakan alat-alat bagi masyarakat sehingga masyarakat dapat ikut mengontrol berjalannya pemerintah daerah di daerahnya sendiri.

Oleh karena itu dengan adanya transparansi pengelolaan keuangan pada Dinas Kesehatan Kota Makassar sudah tentu akan membawa dampak postif kepada dinas itu sendiri, diantaranya yaitu menghilangkan keragu-raguan pemerintah daerah maupun investor-investor dalam pengelolaan keuangan, kepercayaan masyarakat kepada Dinas Kesehatan mengenai pengelolaan keuangan daerah akan semakin meningkat. 


\section{E. KESIMPULAN}

Berdasarkan hasil penelitian yang dilakukan maka penulis menyimpulkan bahwa Transparansi Pengelolaan Keuangan pada Dinas kesehatan kota makassar dengan indikator; (a) variabel penyediaan informasi dengan indikator kejelasan prosedur-prosedur dan kejelasan biaya-biaya belum transparan. (b) Kemudahan akses informasi dengan indikator kemudahan mendapatkan informasi langsung maupun tidak langsung berada pada kategori cukup mudah. (c) Menyusun suatu mekanisme pengaduan jika ada peraturan yang dilanggar atau permintaan untuk membayar uang suap dengan indikator layanan pengaduan belum dilakukan. (d) Meningkatkan arus informasi melalui kerjasama dengan media massa dan lembaga non pemerintah belum dilakukan dan upaya yang dilakukan oleh Dinas kesehatan kota makassar sejauh ini adalah penyampaian laporan pertanggung-jawaban keuangan yang memenuhi prinsip tepat waktu dan dapat diandalkan (reliable) dan telah disahkan sesuai dengan UU yang berlaku dan yang telah diterima secara umum dan Pembuatan website kantor untuk memudahkan mendapatkan informasi baik secara langsung maupun tidak langsung di Dinas kesehatan kota Makassar.

Dengan memperhatikan kesimpulan maka penulis merasa perlu memberikan masukan yaitu agar trasparansi dapat terus menerus ditingkatkan dan disempurnakan maka perlu diperoleh informasi untuk mendapatkan umpan balik dari para pembaca, penerima trasparansi serta dilakukan evaluasi perbaikannya, perlu dibuatkan pilot project pelaksanaan akuntabilitas yang kemudian di komunikasikan kepada seluruh pihak terkait sehingga akan dapat diperoleh ekspektasi mereka dan bagaimana tanggapan mereka mengenai hal tersebut. Penerimaannya suatu kelompok akan suatu hal yang baru akan banyak dipengaruhi oleh pemahaman kelompok pada hal baru tersebut. Tanpa pengetahuan yang komprehensif akan membawa pada penerimaan yang bias dan di perlukan komitmen yang kuat dari seluruh stakeholder dalam hal pengelolaan keuangan yang transparan.

\section{DAFTAR PUSTAKA}

Andrianto, N. 2007. Good Governance : Transparansi dan Akuntabilitas Publik melalui E-government. Malang: Bayumedia Publishing.

Krisna, 2003. Indicator dan Alat Ukur Prinsip Transparansi, Partisipasi dan Akuntabilitas. Yogyakarta : Bumi aksara

Mardiasmo, (2002). Otonomi dan Manajemen Keuangan Daerah, Yogyakarta : PenerbitAndi.

Mardiasmo, 2009. Otonomi dan Manajemen Keuangan Daerah. Yogyakarta : PenerbitAndi.

Mardiasmo, Akuntansi Sektor Publik, 2004. Yogyakarta:PenerbitAndi.

Shende, 2004. Marketing, manajemen : Analisis, Planing, Implementation and Control, 9 Th. Prentice Hall International Int, NewYersey 
Tjahjanulin, 2000. Good Governance "Kepemerintahan yang baik". Jakarta :Bumi Aksara.

Dokumen:

Peraturan Menteri Dalam Negeri Nomor 13 Tahun 2006 tentang azas umum pengelolaan keuangan daerah.

Peraturan Pemerintah Nomor 58 Tahun 2005 tentang Pengelolaan Keuangan Daerah.

Peraturan Menteri Dalam Negeri Nomor 59 Tahun 2007 tentang Pedoman Pengelolaan Keuangan Daerah.

Peraturan Pemerintah Nomor 21 Tahun 2004 tentang Rencana Kerja dan Anggaran Kementerian Negara/ Lembaga.

Peraturan Pemerintah Nomor 24 Tahun 2004 tentang Standar Akuntansi Pemerintahan. 